University of Nebraska - Lincoln

DigitalCommons@University of Nebraska - Lincoln

Faculty Publications: Department of

Entomology

Entomology, Department of

2009

\title{
Adaptation and Invasiveness of Western Corn Rootworm: Intensifying Research on a Worsening Pest
}

\author{
Michael E. Gray \\ University of Illinois at Urbana-Champaign, megray@illinois.edu \\ Thomas W. Sappington \\ USDA-ARS, Corn Insects and Crop Genetics Research Unit, Genetics Laboratory, lowa State University, \\ tom.sappington@ars.usda.gov \\ Nicholas Miller \\ University of Nebraska-Lincoln, nmiller11@iit.edu \\ Joachim Moeser \\ Georg-August University G“"ottingen, jmoeser@gwdg.de \\ Martin O. Bohn \\ University of Illinois at Urbana-Champaign, mbohn@illinois.edu
}

Follow this and additional works at: https://digitalcommons.unl.edu/entomologyfacpub

Part of the Entomology Commons

Gray, Michael E.; Sappington, Thomas W.; Miller, Nicholas; Moeser, Joachim; and Bohn, Martin O., "Adaptation and Invasiveness of Western Corn Rootworm: Intensifying Research on a Worsening Pest" (2009). Faculty Publications: Department of Entomology. 245.

https://digitalcommons.unl.edu/entomologyfacpub/245

This Article is brought to you for free and open access by the Entomology, Department of at DigitalCommons@University of Nebraska - Lincoln. It has been accepted for inclusion in Faculty Publications: Department of Entomology by an authorized administrator of DigitalCommons@University of Nebraska - Lincoln. 


\title{
Adaptation and Invasiveness of Western Corn Rootworm: Intensifying Research on a Worsening Pest*
}

\author{
Michael E. Gray, ${ }^{1}$ Thomas W. Sappington, ${ }^{2}$ \\ Nicholas J. Miller, ${ }^{2}$ Joachim Moeser, ${ }^{3}$ \\ and Martin O. Bohn ${ }^{1}$
}

\author{
${ }^{1}$ Department of Crop Sciences, University of Illinois, Urbana, Illinois 61801; \\ email: megray@illinois.edu,mbohn@illinois.edu \\ ${ }^{2}$ USDA-ARS, Corn Insects and Crop Genetics Research Unit, Genetics Laboratory, \\ Iowa State University, Ames, Iowa 50011; email: Tom.Sappington@ars.usda.gov, \\ nicholas.miller@ars.usda.gov \\ ${ }^{3}$ Department of Crop Sciences, Georg-August University Göttingen, D-37077, \\ Göttingen, Germany; email: jmoeser@gwdg.de
}

Annu. Rev. Entomol. 2009. 54:303-21

The Annual Review of Entomology is online at ento.annualreviews.org

This article's doi:

10.1146/annurev.ento.54.110807.090434

Copyright (c) 2009 by Annual Reviews. All rights reserved

0066-4170/09/0107-0303\$20.00

*The U.S. Government has the right to retain a nonexclusive, royalty-free license in and to any copyright covering this paper.

\section{Key Words}

Diabrotica virgifera virgifera, maize rotation

\section{Abstract}

The western corn rootworm, Diabrotica virgifera virgifera LeConte, is an established insect pest of maize (Zea mays L.) in North America. The rotation of maize with another crop, principally soybeans, Glycine max (L.), was the primary management strategy utilized by North American producers and remained highly effective until the mid-1990s. In 1995, widespread and severe root injury occurred in east-central Illinois and northern Indiana maize fields that had been annually rotated with soybeans on a regular basis for several decades. The failure of this cultural tactic from a pest management perspective was attributed to a behavioral adaptation by a variant western corn rootworm that had lost fidelity to maize for egg laying. In 1992, an infestation of western corn rootworm was found within a small maize field near the Belgrade Airport. By 2007, the presence of this insect pest had been confirmed in 20 European countries. More recent molecular studies have confirmed that at least three separate invasions (until 2004) of western corn rootworms have occurred in Europe, increasing the risk that rotation-resistant western corn rootworms will be introduced into a new continent. Although biological control and use of conventional resistant maize hybrids have not achieved widespread success in the management of western corn rootworms in North America, these tactics are being evaluated in Europe. 


\section{INTRODUCTION}

Variant western corn rootworm: this insect has overcome the pest management benefits of crop rotation by losing its exclusive ovipositional fidelity to maize fields. The variant is often referred to as the rotation-resistant western corn rootworm
The western corn rootworm, Diabrotica virgifera virgifera LeConte, is a significant economic insect pest of maize (Zea mays L.) in the United States and increasingly in Europe. Its history is one of remarkable adaptability and invasiveness. Metcalf (71) estimated yield losses and money spent for the control of the corn rootworm complex (Diabrotica spp.) to be $\$ 1$ billion annually in the United States. Because the western corn rootworm now causes yield losses in rotated and nonrotated maize in the central Corn Belt of the United States, this estimate for North America is now considered low (75). Economic losses on a global scale far exceed the $\$ 1$ billion estimate since the western corn rootworm has continued to spread across Europe $(40,44)$. Larvae of this univoltine chrysomelid feed on roots of maize and some other grass species $(8,9,15,91)$, and adults consume primarily leaf tissue, silks, tender kernels, and pollen (79). The insect overwinters as eggs which are laid in the soil of maize fields from late July through early September and from which larvae hatch the following spring. Its history as a pest of maize during the past half century in the United States, and since the early 1990s in Europe, reflects a remarkable ability to adapt to a broad array of management strategies and to successfully invade new areas. The origins of the western corn rootworm can be traced back to Central America, specifically to Guatemala, where they have been pests of maize for approximately 5000 years (66). Smith \& Lawrence (111) suggested that the western corn rootworm became a more challenging pest after the adoption of the European system of maize production. This production system, introduced by the Spanish, consisted of large tracts of monocultural maize, a significant departure from the more diverse agricultural landscape of Mesoamerica, where scattered patches of maize grew amid other grasses (Setaria spp.) and cucurbits (Cucurbita spp.) (7). Chiang (14) along with Levine \& Oloumi-Sadeghi (56) authored the two primary review articles for the western corn rootworm. Important developments during the past 15 years, including con- siderable expansion in the geographic range of this insect pest (Figure 1), deployment of rootworm-targeting transgenic hybrids, development of resistance to certain insecticides (65), adaptation to crop rotation (60), and advances in our ability to probe the genetic underpinnings and consequences of these changes (42, $72,74,106,109)$, call for an updated review of the literature. Here, we describe the adaptation to crop rotation by a variant western corn rootworm; the invasiveness of western corn rootworm on two continents; intriguing nutritional relationships; and new advances in host plant resistance, biological control, molecular biology, and genetics, with a focus on their relevance in managing this destructive pest.

The western corn rootworm was a resident in the western half of the Great Plains since at least 1867 prior to its expansion across the modern Corn Belt $(14,54)$, and originally was referred to as the Colorado corn rootworm. Presumably native grasses supported low populations when corn was absent $(8,9,15)$. Gillette (26) reported injury to sweet corn caused by the Colorado corn rootworm in 1909, 1910, and 1911. The western corn rootworm continued its eastward expansion, and in 1929 and 1930 root injury was observed in southwestern Nebraska (116). By the mid-1940s, the western corn rootworm and severely damaged maize could be found as far east as central Nebraska. Chiang (14) depicted the rapid range expansion that took place from 1955 to 1970 across maize production areas of the midwestern United States. The large expanse of irrigated and nonrotated maize grown across Nebraska after World War II facilitated the eastward spread of western corn rootworms. By the mid-1980s, the western corn rootworm was reported in western Virginia (123).

Shortly thereafter, in 1992, western corn rootworms were detected within a small field of maize near the Belgrade Airport (2). It remains unclear how this infestation began, but frequent international flights from major airports within the United States located near large maize production areas suggest that accidental transport of adults by commercial aircraft was most likely 


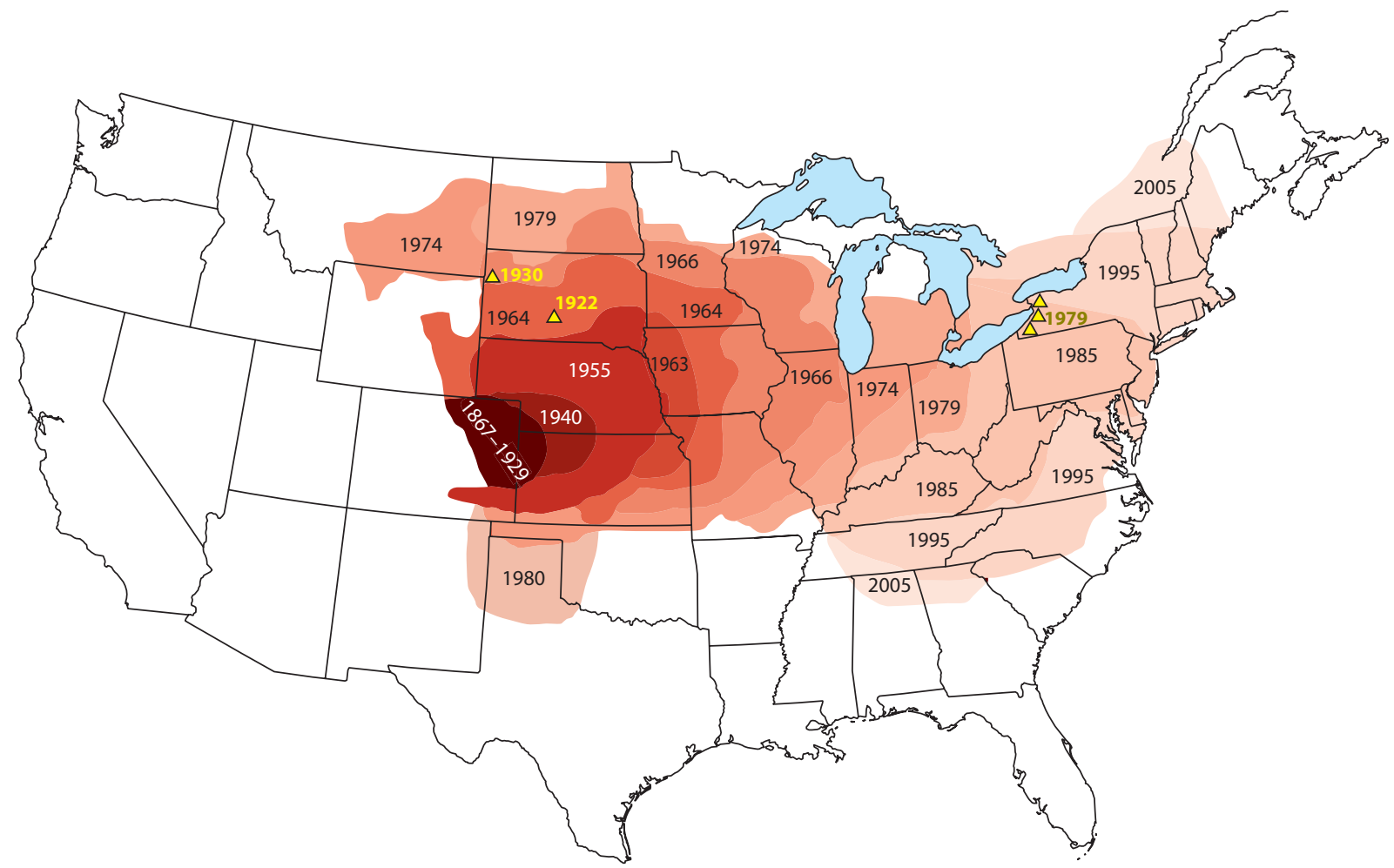

Figure 1

Reconstruction of western corn rootworm, Diabrotica virgifera virgifera LeConte, range expansion from central Great Plains across North America from 1867 to 2005 , based on data or reports in the literature $(25,39,48,49,64,67,68,69,70,110,115,116,123)$. Distribution boundaries are approximate and do not include distributions in areas to the west of the indicated expansion boundaries (see References 48, 114 for western distributions). Triangles mark reports of $D$. v. virgifera far ahead of the established distribution in the years indicated.

the cause. By 2007, western corn rootworms were reported (44) in 20 European countries (Figure 2), with the most significant number of infested hectares in Hungary $\left(93,000 \mathrm{~km}^{2}\right)$, Serbia and Montenegro $\left(73,000 \mathrm{~km}^{2}\right)$, and Romania $\left(65,000 \mathrm{~km}^{2}\right)$. Miller et al. (72) determined that at least three independent incursions by the western corn rootworm across the Atlantic Ocean, rather than a single invasion, are responsible for the current European distribution of this insect pest.

The implication that independent introductions of western corn rootworm into $\mathrm{Eu}-$ rope are an ongoing problem increases the likelihood that a variant (60) of this species, capable of overcoming the pest management benefits of crop rotation, may eventually be introduced (106). Presently, the rotation of maize with a nonhost crop is the primary pest management option for producers throughout Europe (45). If the variant western corn rootworm is discovered in Europe, maize producers most likely will resort initially to seed treatments, followed by soil insecticides and perhaps transgenic maize. The adaptation to crop rotation by the western corn rootworm is a remarkable example of rapid response to natural selection within the agricultural landscape within slightly less than two decades.

\section{ADAPTATION TO CROP ROTATION}

Injury to roots of rotated maize has been described (28) previously for western and northern corn rootworms (Diabrotica barberi Smith 


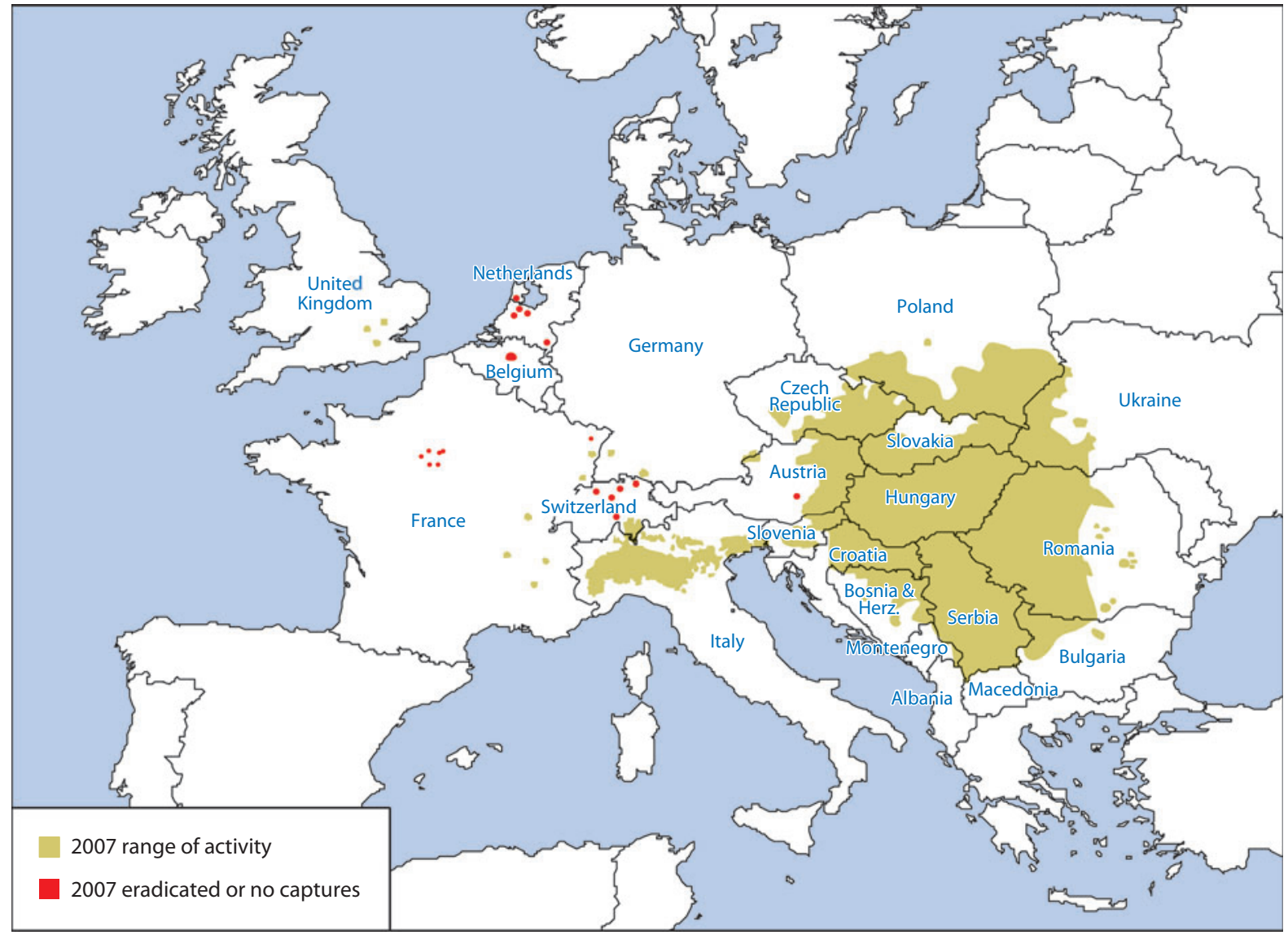

Figure 2

Western corn rootworm, Diabrotica virgifera virgifera LeConte, distribution in Europe through 2007 (with permission of C.R. Edwards, Purdue University).

\& Lawrence). The fundamental mechanisms by which the two species circumvent the pest management benefits of crop rotation are distinctly different. The northern corn rootworm prolongs embryonic diapause $(13,50,59)$, enabling the eggs to survive for more than one winter. Although the western corn rootworm is capable of prolonged embryonic diapause (58), the very low frequency $(<1 \%)$ of this physiological mechanism indicates it is not responsible for the widespread root injury to rotated maize in eastern portions of the United States Corn Belt.

Significant damage to rotated maize by western corn rootworm was first reported in 1987 in Ford County, Illinois, located in the east- central region of the state (57). In less than two decades after invasion of east-central Illinois in 1970 , this insect had seemingly adapted to crop rotation (51). The selection pressure in Ford County may be especially high compared with other areas of the Corn Belt. Approximately $89 \%$ of the land in this county is used for agricultural production, with $98 \%$ of those hectares rotated annually between maize and soybeans, Glycine $\max$ (L.) Merr. $(89,90)$. In this kind of landscape, most larvae that hatch from eggs laid in maize fields by females the preceding summer would die because larvae cannot survive on soybean roots. Thus, the landscape imposes consistent widespread selection pressure to circumvent crop rotation. 


\section{SEARCH FOR THE CAUSAL MECHANISM OF ADAPTATION TO ROTATED MAIZE}

By 1995, maize producers throughout eastcentral Illinois and some areas of northern Indiana observed severe root pruning in their rotated maize fields. The explanation for this widespread injury proved elusive. Prolonged diapause of northern corn rootworm eggs was ruled out owing to the overall low densities of this maize pest and the very low percentage of fields with root injury in rotated maize attributed to this rootworm species in east-central Illinois (113). Pyrethroid repellancy also was suggested as a potential explanation (57). Maize seed production fields are frequently treated with pyrethroids to prevent corn earworm (Helicoverpa zea) injury. Levine \& OloumiSadeghi (57) hypothesized that western corn rootworm females were repelled from maize fields that had been treated with a pyrethroid and laid eggs in adjacent soybean fields. This would result in eggs overwintering in soybean fields and larvae hatching in fields rotated to maize the following spring. As the number of rotated maize fields reported to have significant root damage escalated, this hypothesis was rejected. Shaw et al. (108) documented oviposition by western corn rootworms in Illinois soybean fields infested with volunteer maize. Weed management in soybeans is typically excellent in large-scale commercial fields and, at least initially, oviposition by western corn rootworms in soybean fields was viewed with skepticism as the causal mechanism behind the severe root injury that was occurring in rotated maize. This skepticism was ultimately proven unwarranted $(60,93,94)$. Although it was suggested that a variant of the western corn rootworm was attracted to soybean foliage (105), such attraction could not be verified (112). By the late 1990s, the precise mechanism responsible for the injury to rotated maize by the western corn rootworm in east-central Illinois and northern Indiana remained unclear. O'Neal et al. (85) intensively sampled soybean and maize fields with unbaited Pherocon AM (30) and vial traps (55) in eastern Illinois and determined that the per- centage of female western corn rootworms was greater in soybeans than in maize. Western corn rootworms are visually attracted to the unbaited Pherocon AM traps because of the yellow color of the traps. They subsequently suggested that western corn rootworm females might be laying eggs in soybean fields. Adult samples obtained with Pherocon AM traps in soybean fields explained $27 \%$ of the variation in root injury the following season in rotated maize fields (84).

The maize and soybean agricultural landscape is the dominant ecosystem of the midwestern United States. It is within this nondiverse agricultural system that western corn rootworms and other pests have flourished. Europe has a more varied network of crops (44) that might lend themselves well to rotation schemes to thwart western corn rootworm damage to rotated maize as long as rotationsusceptible rootworms dominate maize production regions. If rotation-resistant rootworms are introduced to Europe, the question becomes whether fields devoted to nonmaize crops will serve as egg-laying sites in the same manner as soybean fields in the U.S. Corn Belt. Western corn rootworm females and eggs have been found in plots of maize, soybean, oat stubble, alfalfa, winter wheat double-cropped with soybeans, and wheat plots in Illinois (101, 102, 107). Although present, the lowest densities of eggs were found in wheat stubble plots compared with other cropping systems. Thus, rotation to crops other than soybeans may offer only limited pest management benefits in maize for this species because of its more general oviposition behavior.

Researchers have begun to understand better the mechanism behind the tendency of variant western corn rootworm females to disperse from maize and lay eggs in fields planted to other crops. In a series of laboratory assays, O'Neal et al. (83) determined that maize phenology influenced soybean foliage consumption by western corn rootworm adults. More soybean leaf tissue was consumed by adults obtained from Illinois, Nebraska, and Michigan as maize senesced. Differences in soybean consumption were not observed among the beetles 


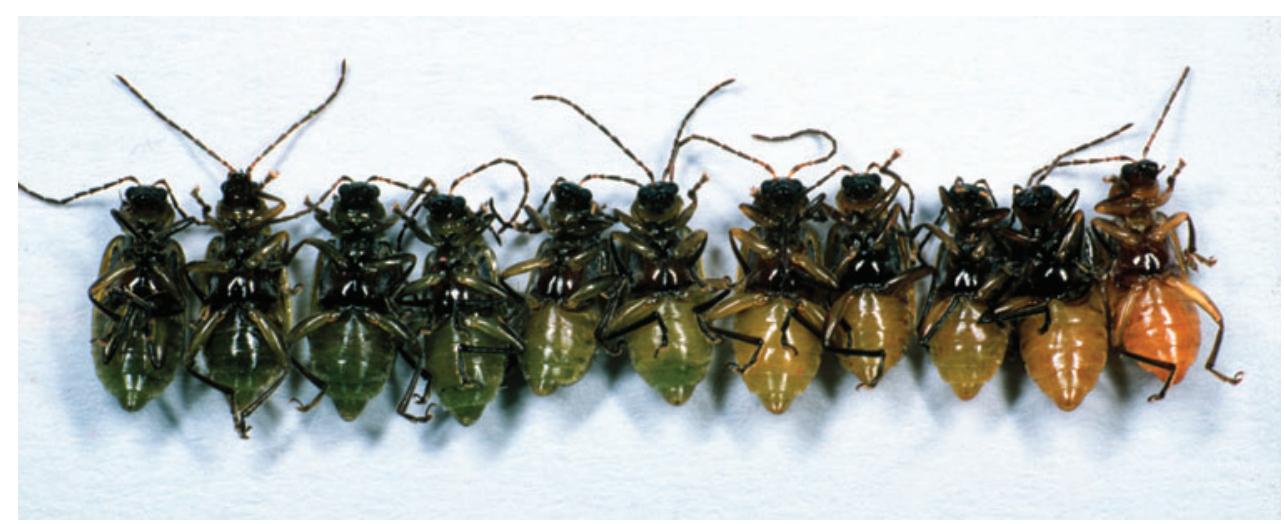

Figure 3

Western corn rootworm females, Diabrotica virgifera virgifera LeConte, with soybean foliage (left) and corn pollen $(r i g h t)$ in their alimentary canal (photograph used with permission of J.L. Spencer, Illinois Natural History Survey).

collected from the three states, suggesting that variant and nonvariant western corn rootworms responded similarly to changes in maize phenology. Western corn rootworm females will consume soybean foliage (Figure 3), but it is a suboptimal diet that induces nutritional stress and behavioral changes such as increased oviposition rate, which could result in oviposition in soybean fields before dispersing back to maize $(62,63)$. Variant females that feed on soybean foliage in the interiors of large commercial fields may undergo nutritional stress sufficient to inhibit dispersal back to maize for egg laying. O’Neal et al. (86) found that western corn rootworm adults responded to changes in maize phenology, moving more readily into olfactometer chambers with soybean leaves as maize matured. Differences in the response to maize phenology were not observed between Illinois (putative variant) and Nebraska (nonvariant) populations, and the authors suggested that the variant behavior could be explained by behavioral plasticity in response to maize phenology and need not be under genetic control (86). However, the well-documented geographic spread of rotation resistance from a point source in Ford County indicates a genetically based trait $(74,89)$. Furthermore, large-scale field experiments involving significant contrasts in maize and soybean phenology indicated that western corn rootworm oviposition behavior differed between variant and nonvariant areas of Illinois (94). Striking differences in western corn rootworm ovipositional responses to crop phenology between beetles inhabiting areas of the state with a history of rotated maize versus nonrotated maize production (94), and oviposition by variant females in soybeans regardless of corn phenology (93), support the hypothesis that adaptation to crop rotation is genetically based. A behavioral activity assay developed by Knolhoff et al. (46) demonstrated differences in mean time to exit an arena of western corn rootworm adults from variant and nonvariant populations, supporting the hypothesis that rotation resistance is a genetic trait. However, the lack of a diagnostic behavioral assay to determine the phenotype of individual beetles has hindered efforts to develop a molecular marker associated with the gene(s) responsible (74).

Since 1995, the rotation-resistant phenotype of the western corn rootworm continues to spread throughout the United States Corn Belt (Figure 4). Models suggest that as cropping diversity across the landscape increases, the rate of spread of rotation resistance in the western corn rootworm will slow (87). If this prediction is accurate, rotation resistance might spread more slowly among western corn rootworm 
populations in Europe than it has across the Corn Belt. However, Onstad et al. (87) also predicted that the rate of evolution to crop rotation in the western corn rootworm increases as the percentage of the agricultural landscape that is rotated increases. Therefore, in as few as 15 years (87) the western corn rootworm could independently evolve a loss of ovipositional fidelity to maize in Europe, even in the absence of accidental introductions. Other modeling analyses $(18,19)$ suggest that in areas where variant western corn rootworms are entrenched, planting transgenic Bt maize targeting rootworms every season may be the optimum economic strategy. Increasingly, producers in large-scale commercial maize production systems, particularly in the United States, have abandoned some important integrated pest management principles and are relying on insecticides or transgenic maize hybrids to control the western corn rootworm without the use of scouting information or economic thresholds. European producers now forced to deal with this pest have the opportunity to manage it in a more integrated manner from the outset, learning from the mistakes made in the United States that led to the development of insecticide resistance on multiple occasions $(3,65)$.

\section{WESTERN CORN ROOTWORM NUTRITIONAL ECOLOGY: EMERGING EUROPEAN PERSPECTIVES}

The invasion of Europe by the western corn rootworm raised many questions regarding its nutritional ecology due to potential changes in its biology that may have resulted from genetic bottlenecks during the introduction process (72). In addition, a more diverse European agricultural landscape consisting of numerous organic farms alongside traditional commercial farms of many sizes $(22,120)$ has prompted an examination of the nutritional relationships of western corn rootworms with their potential new hosts. Regional differences make it virtually impossible to generalize the characteristics of European maize production

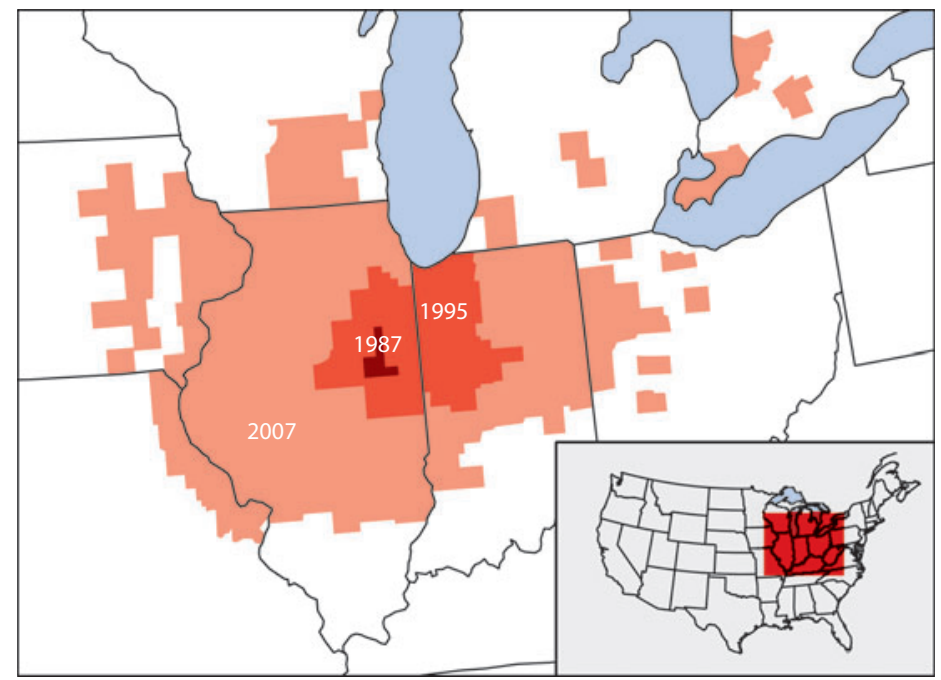

Figure 4

Range expansion of the variant western corn rootworm, Diabrotica virgifera virgifera LeConte, in the United States Corn Belt through 2007.

systems, but it is widely accepted that European farmers use a more diverse array of cropping systems (45), rotate more often with a greater variety of crops, and frequently utilize relatively small fields compared with farmers in the U.S. Corn Belt. However, in some areas of Europe, such as the southern Rhine Valley of Germany, large maize fields are used for grain production.

Currently, no data are available that indicate genetic bottlenecks had any influence on the use of maize as a host plant by European western corn rootworm populations. Multiple introductions into Europe (74) make this prospect less likely once the populations have merged. At present, maize is considered the main host plant in Europe (76). Progress has been slow in understanding the physiology of western corn rootworm and its nutritional requirements. It remains unclear what makes a certain maize hybrid a more suitable nutritional resource. $\mathrm{Ni}$ trogen levels, along with phytosterol and fiber content of root systems, had a strong influence on larval feeding and a less pronounced effect on larval development among European maize hybrids $(78,80)$. Assabgui et al. (1) showed that a high content of hydroxamic acids in certain plant stages had a negative effect on larval
Genetic bottleneck: an event that results in a reproductive isolation of a smaller group of individuals from the main population of a species, resulting in a narrower germplasm for natural selection to act upon 
development among nine elite inbred lines, but Davis et al. (20) found no such effects in four lines.

Thus far, investigations on the nutritional ecology of western corn rootworms have led to similar findings in Europe and the United States $(15,77,91)$, but research in both locations using the same methodology is warranted. Some research within the United States has focused on determining the suitability of native prairie grasses as hosts (91). Other nonmaize host plant studies focused on the potential implications of resistance development to transgenic maize if western corn rootworm larvae utilize grassy weeds as alternative hosts after hatch and then move to $B t$ maize $(12,121)$. It remains unknown whether alternative hosts may undermine eradication and containment efforts in Europe. It seems probable that western corn rootworm populations will survive in the complete absence of maize on some European grass species (e.g., Setaria spp.), which they can exploit with nearly the same efficiency as maize (76). If alternative hosts are commonly used, eradication efforts in Europe will most likely be futile over the long term. Successful eradication programs in the Netherlands, Belgium, and northern Switzerland (97) suggest that crop rotation is still worthwhile and should be continued as part of an overall program. If rotation resistance is ultimately introduced or evolves independently in Europe, crop rotation may not offer a consistently reliable management strategy.

Another concern for European agriculture lies in a potential host switch to other monocot crops used in the rotation systems. Maize is rotated frequently with potential host plants of western corn rootworm like winter wheat (Triticum aestivum L.) or rye (Secale cereale L.) in Europe. Moeser \& Vidal (77) suggest that most monocot crops grown in Europe could be used successfully by western corn rootworm. Data collected in Germany and modeled for local temperature conditions suggest that the phenology of western corn rootworm larval hatch and the development of alternative monocot crops may coincide (4). In these regions, avoid- ance of large-scale rotations with cereal crops should be considered.

The impressive dispersal capacity $(16,27)$ of western corn rootworm adults and the close proximity of diverse fields in Europe expose adults to a great variety of potential host plants. Western corn rootworms have been observed in southeastern Europe dispersing from maize fields to feed on other plants such as sunflower (Helianthus annuus), alfalfa (Medicago sativa), or flowering weeds present in field margins (79). Campbell \& Meinke (11) reported that western corn rootworms moved frequently between the maize and prairie interface in east and central Nebraska study sites depending on the phenology of plants that served as food sources. They suggested that knowledge gained from a more landscape-focused approach rather than a fieldby-field basis would be helpful in improving the management of western corn rootworms. IgrcBarcic et al. (34) found western corn rootworm adults in neighboring fields up to $50 \mathrm{~m}$ from maize field margins. This dispersal into adjacent nonmaize crops resulted in egg laying and subsequent larval damage in rotated maize the following season up to $20 \mathrm{~m}$ from the field border. This dispersal and egg-laying behavior creates significant management challenges for producers in eastern Europe because many crops are produced in narrow strips ( $<50 \mathrm{~m}$ wide); reports of problems in rotated maize are common in Croatia and Hungary. Egg laying by western corn rootworms in narrow strips of nonmaize crops, such as soybean, has been reported previously in the United States (118). Therefore, this observed behavior in Europe should not be assumed to represent the aberrant behavior of the variant western corn rootworm that results in oviposition in the interiors of large, commercial, nonmaize fields.

\section{BIOLOGICAL CONTROL AND HOST PLANT RESISTANCE: REALISTIC MANAGEMENT OPTIONS IN EUROPE?}

Considerable research efforts are underway to determine the feasibility of biological control 
as a management option in Europe (24). Thus far, not surprisingly, surveys have not found any specialized native natural enemies in Europe. Several species of parasitoids (primarily Celatoria compressa, Tachinidae) from Mexico have been evaluated for their potential use in a mass propagation and release program (52). Although entomopathogenic nematodes have never been successfully commercialized for large-scale western corn rootworm control programs in the United States, they are currently viewed as the most promising biocontrol option in Europe. Limited successes $(36,38)$ with control via nematodes in the United States have been documented, but this agent appears most promising when used in conjunction with center-pivot irrigation systems (122).

The search for native European nematodes has revealed several species that could be used inundatively (117). Heterorbabditis bacteriophora Poinar, H. megidis Poinar, and Steinernema feltiae Filipjev were screened in three maize fields in southern Hungary using an insectbaiting technique. Field trials showed that all three species established and persisted for 2 to 5 months as long as western corn rootworm larvae were present in the soil (53). These results demonstrate the biological control potential of these nematode species when used in a therapeutic fashion. Applications of nematodes both at planting and when larvae first appear are being evaluated to determine if efficacy can be improved. Toepfer et al. (117) found that western corn rootworm larval mortality rates were greatest when treated with H. bacteriophora $(77 \pm 16.6 \%)$, Steinernema arenarium $(67 \pm 3.5 \%)$, and S. feltiae $(57 \pm$ $17.1 \%)$ under laboratory conditions. Intriguing and surprising multitrophic interactions have been revealed in which a $\beta$-caryophyllene gradient around damaged maize plants attracts entomopathogenic nematodes that subsequently infest western corn rootworm larvae feeding on roots (99).

The role of entomopathogenic fungi with regard to potential population suppression of western corn rootworms is still largely unknown. Pilz et al. (96) reported a low natural infection of field-collected western corn rootworms $(1.4 \%$ of larvae, $0.2 \%$ of pupae, and $0.05 \%$ adults) by Metarrbizium anisopliae and Beauveria spp. A screening of field and laboratory fungal strains revealed a greater virulence of field strains. The virulence was greatest in M. anisopliae, resulting in infection rates as high as $47 \%$ for larvae and $97 \%$ for adults under laboratory conditions (95). Studies with Diabrotica speciosa (Germar) showed greater mortality rates with Beauveria spp. (70\%) than with $M$. anisopliae (43\%) (17). Other investigations with Diabrotica species showed variable results regarding the infection rates of $M$. anisopliae and Beauveria bassiana $(10,47)$. Socioeconomic evaluations reveal a potential market for biological control of western corn rootworms in European organic maize and maize seed production fields (24).

A rigorous survey of Corn Belt maize germplasm in the 1930s and 1940s detected significant genotypic variation for western corn rootworm resistance (6). In the following years, a few inbred lines with improved resistance to corn rootworm larval feeding were developed (37). These lines were characterized by large, densely branched root systems and the ability for quick root regeneration after corn rootworm injury. Thus, the predominant resistance mechanism against western corn rootworm injury was tolerance. Riedell \& Evenson (100) also characterized maize hybrids grown in the northern United States as primarily offering tolerance against corn rootworm root injury, not antibiosis.

There are some possible explanations for the lack of significant improvement in the introgression of antibiosis in maize hybrids over the past 60 years. In the initial screening phase, most breeding programs evaluated germplasm for its resistance to root lodging (standability of maize plants). This characteristic is associated with root size and indirectly determines the level of tolerance to western corn rootworm larval injury. In contrast, correlation coefficients between root size and root injury ratings, a measure of antibiosis, are low (29). As a result, it is likely that genotypes with interesting antibiotic properties were not identified. 
United States

Department of

Agriculture

Agricultural

Research Service

(USDA ARS): branch

of the U.S.

Government

responsible for the

administration and

conduct of agricultural

research

Quantitative trait

locus (QTL): a

chromosomal region

carrying a gene or

multiple genes

involved in the

inheritance of a

quantitative trait

Invasive species: a species that suddenly increases its geographical distribution
Most breeding programs improved tolerance but not antibiosis. More than 3500 accessions of maize and maize relatives were screened for resistance to western corn rootworm larval feeding by USDA ARS scientists at the University of Missouri between 1992 and 1999. Based on this germplasm screening, seven accessions with reduced root injury ratings were found. Four of these genotypes confirmed their level of resistance in a diallel study and were recombined to start a recurrent selection program (32). However, no information about the underlying resistance mechanism is yet available. This breeding program focuses on root injury evaluations using artificial infestation with western corn rootworm eggs. With the use of molecular marker techniques, host plant resistance breeding programs may begin to make more rapid progress in selecting for antibiosis in maize hybrids against this insect.

Scientists at the USDA ARS laboratory in Columbia, Missouri, University of Illinois, and the University of Missouri are conducting research to locate putative western corn rootworm resistance quantitative trait loci (QTL) and to estimate their genetic effects using a segregating population of $\mathrm{F}_{2: 3}$ families derived from the cross between a susceptible inbred line and multiple resistant individuals selected from an advanced cycle of the USDA ARS Missouri breeding program. In addition, scientists at the University of Illinois and University of Missouri are evaluating the response of maize to western corn rootworm feeding in a coherent framework of available methods comprising microarrays and metabolite analysis. These studies have detected more than 700 different biochemical compounds. By integrating genetic and genomic tools, researchers anticipate that greater progress will be made in the development of nontransgenic maize hybrids with antibiosis against western corn rootworms. These resistant maize hybrids would gain quick acceptance across Europe, assuming yields of these cultivars remain competitive. Within the United States there will likely be less demand for these nontransgenic resistant maize hybrids owing to the broad and escalating acceptance of transgenic $B t$ hybrids.

\section{GENETICS OF INVASION AND ADAPTATION}

Successful invasion of new territory by an organism occurs in three stages: (a) colonization by founders, (b) establishment of a growing, self-sustaining population, and (c) secondary range expansion beyond the area of initial establishment through dispersal $(61,104)$. The secondary range expansion itself involves the same stages as individuals disperse, colonize, and establish viable populations in new territory, creating an invasion front. In invasive species such as the western corn rootworm, genetic diversity is, to a large degree, shaped by the dynamics of the invasion process. Although the effects on fitness may be unpredictable, introductions of alien species typically entail founder effects that reduce variability with respect to the source population (119). The effects of these demographic shifts on genetic diversity are predictable (31), so examining genetic diversity reveals information about the demographic history of an invader $(21,92)$. Because the variation in an introduced population is a sample of that present in the ancestral population, analyzing genetic variation can be a powerful technique for revealing the source of invaders, provided that the potential source populations are genetically differentiated $(72,92,98)$.

The ongoing invasion of Europe by the western corn rootworm is an example of colonization and range expansion by an exotic insect, whereas the invasion of the United States Corn Belt and eastern North America occurred when populations indigenous to the Great Plains began expanding their range in the 1940s, reaching the East Coast by the mid1980s (Figure 1). Although the circumstances initiating the two invasions differ, the fundamental processes governing range expansion are the same. During the range expansion in North America, founder populations often established far ahead of the advancing invasion 
front $(14,103,123)$, a phenomenon resulting from a process of stratified dispersal (61). Within a few years, these satellite populations coalesced with the advancing main population, which swamped any genetic founder effects. Indeed, population genetics analyses show high genetic variation but no significant differentiation from Kansas to New York, suggesting that there has not yet been enough time for genetic drift to perturb the expansion's legacy of genetic homogenization (42) and create a pattern of isolation by distance. Stratified dispersal results in a much more rapid rate of expansion than do population growth and short-range dispersal alone at the leading edge of the front. Importantly, this rate accelerates as the length of the front increases (61). This phenomenon probably accounts for Metcalf's (70) observation of the accelerating rate of spread of the western corn rootworm across the Corn Belt, which he understandably, but mistakenly, attributed to the coincidental development of cyclodiene resistance in the early 1960s. Rates of expansion varied tremendously across North America, ranging from 20 to $200 \mathrm{~km} /$ year (65), and depended in part on the direction of spread relative to prevailing winds and storm fronts that aid long-distance dispersal $(35,89)$. Spread was slowed in areas of intense crop rotation (123), which affects establishment potential of longdistance colonizers.

Superficially, the spread of resistance to crop rotation has some similarity to the species' eastward range expansion, with satellite pockets of resistance occurring ahead of the advancing resistance front (87). There is, however, an important distinction to be made between the spread of adaptive alleles through a population and a distinct, genetically coherent strain displacing wild-type populations. Deterministic population genetics simulations have shown that a single locus model with an allele for reduced fidelity to maize is sufficient to explain the evolution of the variant behavior, given the selection pressure exerted by nearly exclusive rotation of maize with soybeans in east-central Illinois (90). Evidence from microsatellites shows that variant and wild-type populations do not differ at neutral loci (74). Thus, it seems that dispersing variant adults are spreading alleles that confer reduced host fidelity and therefore should not be characterized as a distinct strain. Similarly, the spread of cyclodiene resistance is best understood as the spread of resistance alleles, rather than the spread of a behaviorally different strain (70). Alleles, however, travel in bodies, and understanding individual dispersal has proved useful in predicting the spread of variant behavior (87).

Identifying the gene or genes at which this adaptation is taking place would be tremendously helpful. Models that attempt to predict the effectiveness of different management tactics have made critical assumptions about the genetic control of the variant trait $(19,88)$. It is unclear how well these assumptions approximate reality or what the consequences for management will be if they are incorrect. Identifying a genetic marker would provide a convenient early warning for future spread of the variant. Although significant progress has been made in understanding the variant phenotype at a population level, no diagnostic techniques have been developed to classify an individual's phenotype. This has largely precluded QTL analyses of the adaptation. Attempts to identify linked loci via genome scanning in natural populations identified an amplified fragment length polymorphism (AFLP) marker weakly associated with variants (73), but a diagnostic marker remains elusive. The genome scanning approach probably is impeded by the large size of the western corn rootworm genome (106). A more fruitful avenue of research for the future may be to target candidate genes that play a role in movement, feeding, or oviposition behavior. Some initial progress is being made in this direction and a large collection of expressed sequence tag (EST) sequences from western corn rootworm head tissues was recently deposited with GenBank (H. Robertson et al., Accessions EW761110-EW777362). Another option may be to focus genome scanning efforts on the transcribed portion of the genome.

Genetic analyses have been instrumental in understanding the sequence of events by
Genome scanning: studying genetic divergence between populations at large numbers of loci to identify outliers that may be affected by natural selection

Amplified fragment length polymorphism (AFLP): a DNA fingerprinting technique that can be used to easily and cheaply identify many polymorphisms in otherwise uncharacterized genomes

Expressed sequence $\operatorname{tag}$ (EST): a sequence derived from messenger RNA. EST libraries provide a snapshot of the genes expressed in a set of tissues under specific circumstances 
Approximate

Bayesian

computation (ABC):

a method of Bayesian

inference that can be

used with complex

models for which

likelihood functions

cannot be obtained

Bacterial artificial chromosome (BAC): a tool used for cloning very large fragments of DNA and for constructing physical maps of genomes which western corn rootworm has been invading Europe. The ongoing monitoring efforts to track the spread of western corn rootworm in Europe have resulted in an unusually detailed picture of when outbreaks first occurred in particular locations. These historical observations can be integrated with genetic data using approximate Bayesian computation (ABC), a powerful and flexible technique that is becoming popular for the analysis of genetic data under complex demographic situations (5). An $\mathrm{ABC}$ analysis of microsatellite data from several European outbreaks and the United States Corn Belt (72) revealed a surprisingly complex introduction history. In addition to the initial introduction into Serbia and subsequent spread, there have been at least two additional introductions from North America, one into Italy and one into France. Since this analysis was done, additional Western European outbreaks have been observed, notably in France, the United Kingdom, and Germany. Going forward, further research will be required to determine the origins of new outbreaks as they occur. The success of founding populations can be negatively affected by the associated loss of genetic diversity (61), but multiple introductions into the same location, or eventual melding of disjunct populations, may help mitigate the initial loss.

The observation that there have been multiple transatlantic introductions of western corn rootworms within just a few years raises a number of questions about why the rate of successful introductions has, apparently, suddenly increased. Generally, new biological invasions require either a change in migration patterns, a change in the destination environment to render it vulnerable to invasion, or evolution by the organism to allow it to invade a new environment (23). An obvious candidate is the increasing international air travel between North America and Europe. It will be important to determine the minimum size of a founding population necessary to become established (61) and population genetic analysis will be useful in that regard. It is unlikely that a single gravid female on an air passenger's pant leg would be adequate to initiate an infestation (81). It seems more likely that multiple individuals must be transported simultaneously in airplane cargo holds. If air transport is responsible, it is intriguing that the northern corn rootworm (Diabrotica barberi Smith and Lawrence), which shares a significant part of its North American distribution with western corn rootworms, has never been observed in Europe. This may hold clues to the locations of American source populations, which, owing to the genetic homogeneity of western corn rootworms in North America (42), has proved difficult to determine. Alternatively, the absence so far of the northern corn rootworm may suggest that the western corn rootworm species is more likely to enter aircraft or is better able to establish itself with smaller founding populations than the former. Equally, comparing the ecological requirements of the two species and the match that European agroecosystems provide them may prove instructive (33).

Population genetics will continue to be applied to questions of western corn rootworm ecology and invasion for many years, and the recent development of a recommended core set of microsatellite markers (43) will facilitate direct comparisons between studies and data sharing among laboratories. Laboratory lines of western corn rootworms selected for resistance to transgenic $B t$ toxins (82) will provide important insights into the genetics of resistance. Another future thrust in western corn rootworm genetics research will be in the realm of genomics. The large size of the genome $(\sim 2.5 \mathrm{Gbp})$ will be a significant barrier to a genome sequencing project for a few years. In the meantime, construction and sequencing of new EST libraries, linkage mapping, and characterization of bacterial artificial chromosome (BAC) libraries will provide resources for gene discovery, marker development, and genetic analysis. Existing EST (109) and BAC-end sequences will be a rich source of microsatellite and single nucleotide polymorphism markers for linkage mapping and population genetics (41). 


\section{SUMMARY POINTS}

1. The variant western corn rootworm has lost its ovipositional fidelity to maize and lays eggs in a variety of other crops, most notably soybeans, in the Corn Belt of the United States, negating the pest management benefits of crop rotation.

2. The adaptation to crop rotation by the western corn rootworm occurred within two decades after the invasion of east-central Illinois, a region characterized by the annual rotation of two crops, maize and soybeans.

3. Range expansion of the western corn rootworm is characterized by the process of stratified dispersal, in which disjunct satellite populations are established by founders that disperse ahead of the main front. This process accelerates the rate of range expansion as the front lengthens, a phenomenon observed for the western corn rootworm as it spread eastward across North America but misinterpreted at the time. Europe can expect the same phenomenon of accelerated rate of spread as its expansion front lengthens.

4. The spread of variant western corn rootworm behavior is due to the spread of adaptive alleles through the population. Variant western corn rootworms are not a genetically isolated strain reproductively isolated from their wild-type counterparts.

5. Multiple introductions of western corn rootworm from North America into Europe increase the probability that the variant adaptation is present or will become present in European populations. This may threaten the long-term efficacy of crop rotation as a pest management tactic in Europe.

6. Neither the development of viable biological control approaches nor the use of resistant (nontransgenic) maize hybrids has achieved widespread success or implementation in North America. In Europe, these approaches are being evaluated for potential usefulness.

\section{FUTURE ISSUES}

1. A future thrust in western corn rootworm genetics research will be in the realm of genomics. The large size of the genome $(\sim 2.5 \mathrm{Gbp})$ will be a significant barrier to a genome sequencing project for a few years.

2. Identifying the allele(s) responsible for reduced ovipositional fidelity to maize by variant western corn rootworms will continue to be an intriguing research challenge.

3. Aided with improved and affordable molecular marker techniques, traditional host plant breeding programs may develop corn rootworm-resistant (nontransgenic) maize hybrids.

4. Research will continue in Europe for potential biological control agents against western corn rootworm.

5. An examination of the nutritional ecology between alternative host plants and western corn rootworms will be a continuing research thrust in Europe.

\section{DISCLOSURE STATEMENT}

The authors are not aware of any biases that might be perceived as affecting the objectivity of this review. 


\section{ACKNOWLEDGMENTS}

We thank the following scientists who provided information concerning the dispersal of the variant western corn rootworm into their state or province: Eileen Cullen (University of Wisconsin), Chris DiFonzo (Michigan State University), Rich Edwards (Purdue University), Bruce Hibbard (USDA ARS, Columbia Missouri), Clint Pilcher (Monsanto Company), Patricia Prasifka (Iowa State University), Jocelyn Smith (University of Guelph), and Curtis Young (Ohio State University).

\section{LITERATURE CITED}

1. Assabgui RA, Arnason JT, Hamilton RI. 1995. Field evaluations of hydroxamic acids as antibiosis factors in elite maize inbreds to the western corn rootworm (Coleoptera: Chrysomelidae). 7. Econ. Entomol. 8:1482-93

2. Described the first known western corn rootworm infestation in Europe.

8. Quantified the survivorship of western corn rootworm on potential alternative hosts.

16. Established minimum long-range flight potential parameters of migratory western corn rootworm adults.
2. Baca F. 1994. New member of the harmful entomofauna of Yugoslavia Diabrotica virgifera virgifera LeConte (Coleoptera: Chrysomelidae). Zast. Bilja 45:125-31

3. Ball HJ, Weekman GT. 1963. Differential resistance of corn rootworms to insecticides in Nebraska and adjoining states. 7. Econ. Entomol. 56:553-55

4. Baufeld P, Enzian S. 2006. Abschätzung der Entwicklung von Diabrotica virgifera virgifera in alternativen Kulturpflanzen unter den klimatischen Bedingungen Deutschlands. Mitt. Biol. Bundeanstalt 400:447

5. Beaumont MA, Zhang WY, Balding DJ. 2002. Approximate Bayesian computation in population genetics. Genetics 162:2025-35

6. Bigger JH. 1941. Breeding corn for resistance to insect attack. F. Econ. Entomol. 34:341-47

7. Branson TF, Krysan JL. 1981. Feeding and oviposition behavior and life cycle strategies of Diabrotica: an evolutionary view with implications for pest management. Environ. Entomol. 10:826-31

8. Branson TF, Ortman EE. 1967. Host range of larvae of the western corn rootworm. F. Econ. Entomol. 60:201-3

9. Branson TF, Ortman EE. 1970. The host range of larvae of the western corn rootworm: further studies. 7. Econ. Entomol. 63:800-3

10. Bruck DJ, Lewis LC. 2001. Adult Diabrotica spp. (Coleoptera: Chrysomelidae) infection and emergence with indigenous Beauveria bassiana. 7. Invertebr. Pathol. 77:288-89

11. Campbell LA, Meinke LJ. 2006. Seasonality and adult habitat use by four Diabrotica species at prairie-corn interfaces. Environ. Entomol. 35:922-36

12. Chege PG, Clark TL, Hibbard BE. 2005. Alternate host phenology affects survivorship, growth, and development of western corn rootworm (Coleoptera: Chrysomelidae) larvae. Environ. Entomol. 34:144147

13. Chiang HC. 1965. Survival of northern corn rootworm eggs through one and two winters. F. Econ. Entomol. 58:470-72

14. Chiang HC. 1973. Bionomics of the northern and western corn rootworms. Annu. Rev. Entomol. 18:47-72

15. Clark TL, Hibbard BE. 2004. Comparison of nonmaize hosts to support western corn rootworm (Coleoptera: Chrysomelidae) larval biology. Environ. Entomol. 33:681-89

16. Coats SA, Tollefson JJ, Mutchmor JA. 1986. Study of migratory flight in the western corn rootworm (Coleoptera: Chrysomelidae). Environ. Entomol. 15:1-6

17. Consolo VF, Salerno GL, Beron CM. 2003. Pathogenicity, formulation and storage of insect pathogenic hyphomycetous fungi tested against Diabrotica speciosa. Biocontrol 48:705-12

18. Crowder DW, Onstad DW, Gray ME. 2006. Planting transgenic insecticidal corn based on economic thresholds: consequences for integrated pest management and insect resistance management. F. Econ. Entomol. 99:899-907

19. Crowder DW, Onstad DW, Gray ME, Mitchell PD, Spencer JL, et al. 2005. Economic analysis of dynamic management strategies utilizing transgenic corn for control of western corn rootworm (Coleoptera: Chrysomelidae). F. Econ. Entomol. 98:961-75

20. Davis SC, Ni X, Quisenberry SS, Foster JE. 2000. Identification and quantification of hydroxamic acids in maize seedling root tissue and impact on western corn rootworm (Coleoptera: Chrysomelidae) larval development. 7. Econ. Entomol. 93:989-92 
21. Estoup A, Beaumont M, Sennedot F, Moritz C, Cornuet JM. 2004. Genetic analysis of complex demographic scenarios: spatially expanding populations of the cane toad, Bufo marinus. Evolution 58:2021-36

22. Eurostat. 2007. http://epp.eurostat.ec.europa.eu

23. Facon B, Genton BJ, Shykoff J, Jarne P, Estoup A, David P. 2006. A general eco-evolutionary framework for understanding bioinvasions. Trends Ecol. Evol. 21:130-35

24. Fall EH, Wesseler J. 2007. Report on market analyses for the potential use of biological control products in high value maize systems in Europe (WP 2 Task 3). EU Funded Proj. Rep. FP6-2004-SSP-4-022623. $32 \mathrm{pp}$.

25. Foott WH, Timmins PR. 1977. Observations on new insect pests of grain corn in Essex County, Ontario. Proc. Entomol. Soc. Ont. 108:49-52

26. Gillette CP. 1912. Diabrotica virgifera Lec. A corn rootworm. 7. Econ. Entomol. 5:364-66

27. Grant RH, Seevers KP. 1989. Local and long-range movement of adult western corn rootworm (Coleoptera: Chrysomelidae) as evidenced by washup along southern Lake Michigan shores. Environ. Entomol. 18:266-72

28. Gray ME, Levine E, Oloumi-Sadeghi H. 1998. Adaptation to crop rotation: western and northern corn rootworms respond uniquely to a cultural practice. Rec. Res. Dev. Entomol. 2:19-31

29. Gray ME, Steffey KL. 1998. Corn rootworm (Coleoptera: Chrysomelidae) larval injury and root compensation of 12 maize hybrids: an assessment of the economic injury index. F. Econ. Entomol. 91:723-40

30. Hein GL, Tollefson JJ. 1985. Use of the Pherocon AM trap as a scouting tool for predicting damage by corn rootworm (Coleoptera: Chrysomelidae) larvae. 7. Econ. Entomol. 78:200-3

31. Hein J, Schierup MH, Wiuf C. 2005. Gene Genealogies, Variation and Evolution: A Primer in Coalescent Theory. Oxford: Oxford Univ. Press. 296 pp.

32. Hibbard BE, Darrah LL, Barry BD. 1999. Combining ability of resistance leads and identification of a new resistance source for western corn rootworm (Coleoptera: Chrysomelidae) larvae in corn. Maydica 44:133-39

33. Hierro JL, Maron JL, Callaway RM. 2005. A biogeographical approach to plant invasions: the importance of studying exotics in their introduced and native range. F. Ecol. 93:5-15

34. Igrc-Barcic J, Bazok R, Edwards CR, Kos T. 2007. Western corn rootworm adult movement and possible egg laying in fields bordering maize. F. Appl. Entomol. 131:400-5

35. Isard SA, Spencer JL, Mabry TR, Levine E. 2004. Influence of atmospheric conditions on high-elevation flight of western corn rootworm (Coleoptera: Chrysomelidae). Environ. Entomol. 33:650-56

36. Jackson JJ. 1996. Field performance of entomopathogenic nematodes for suppression of western corn rootworm (Coleoptera: Chrysomelidae). F. Econ. Entomol. 89:366-72

37. Jenison JR, Shank DB, Penny LH. 1981. Root characteristics of 44 maize inbreds evaluated in four environments. Crop Sci. 21:233-37

38. Journey AM, Ostlie KR. 2000. Biological control of the western corn rootworm (Coleoptera: Chrysomelidae) using the entomopathogenic nematode, Steinernema carpocapsae. Environ. Entomol. 29:822-31

39. Kantack BH. 1965. Western corn rootworm in South Dakota. Proc. N. Centr. Br. Entomol. Soc. Am. 20:62-63

40. Kaster LV, Gray ME. 2005. European corn borers and western corn rootworms: old and new invasive maize pests challenge farmers on European and North American continents. Maydica 50:235-45

41. Kim KS, Ratcliffe ST, French BW, Liu L, Sappington TW. 2008. Utility of EST-derived SSRs as population genetics markers in a beetle. 7. Hered. 99:112-24

42. Kim KS, Sappington TW. 2005. Genetic structuring of western corn rootworm (Coleoptera: Chrysomelidae) populations in the U.S. based on microsatellite loci analysis. Environ. Entomol. 34:494-503

43. Kim KS, Stolz U, Miller NJ, Waits ER, Guillemaud T, et al. 2008. A core set of microsatellite markers for western corn rootworm (Coleoptera: Chrysomelidae) population genetics studies. Environ. Entomol. 37:293-300

44. Kiss J, Edwards CR, Berger HK, Cate P, Cean M, et al. 2005. Monitoring of western corn rootworm (Diabrotica virgifera virgifera LeConte) in Europe 1992-2003. In Western Corn Rootworm: Ecology and Management, ed. S Vidal, U Kuhlman, CR Edwards, 2:29-39. Wallingford, UK: CAB Int. 320 pp. 
57. The first report of the variant western corn rootworm damaging first-year maize.

60. Described how the annual rotation of maize and soybean had selected for the rotation resistant western corn rootworm.

61. Describes the dynamics of range expansion after an insect invasion.
45. Kiss J, Komáromi J, Bayar K, Edwards CR, Hatala-Zsellér I. 2005. Western corn rootworm (Diabrotica virgifera virgifera LeConte) and the crop rotation systems in Europe. In Western Corn Rootworm: Ecology and Management, ed. S Vidal, U Kuhlman, CR Edwards, 10:189-220. Wallingford, UK: CAB Int. 320 pp.

46. Knolhoff LM, Onstad DW, Spencer JL, Levine E. 2006. Behavioral differences between rotationresistant and wild-type Diabrotica virgifera virgifera (Coleoptera: Chrysomelidae). Environ. Entomol. 35:1049-57

47. Krueger SR, Roberts DW. 1997. Soil treatment with entomopathogenic fungi for corn rootworm (Diabrotica spp.) larval control. Biol. Control 9:67-74

48. Krysan JL. 1986. Introduction: biology, distribution, and identification of pest Diabrotica. In Methods for the Study of Pest Diabrotica, ed. JL Krysan TA Miller, pp. 25-47. New York: Springer. 260 pp.

49. Krysan JL, Smith RF, Branson TF, Guss PL. 1980. A new subspecies of Diabrotica virgifera (Coleoptera: Chrysomeldae): description, distribution, and sexual compatibility. Ann. Entomol. Soc. Am. 73:123-30

50. Krysan JL, Foster DE, Branson TF, Ostlie KR, Cranshaw WS. 1986. Two years before the hatch: rootworms adapt to crop rotation. Bull. Entomol. Soc. Am. 32:250-53

51. Kuhlman DE, Randell R. 1971. Insect situation, 1971. Proc. 23rd Illinois Custom Spray Operators Training School, pp. 66-85. Coop. Ext. Serv., Univ. Ill., Urbana-Champaign

52. Kuhlmann U, Toepfer S, Zhang F. 2005. Is classical biological control against western corn rootworm in Europe a potential sustainable management strategy? In Western Corn Rootworm: Ecology and Management, ed. S Vidal, U Kuhlmann, CR Edwards, 13:263-84. Wallingford, UK: CABI Publ. 320 pp.

53. Kurtz B, Toepfer S, Ehlers RU, Kuhlmann U. 2007. Assessment of establishment and persistence of entomopathogenic nematodes for biological control of western corn rootworm. F. Appl. Entomol. 131:420-25

54. LeConte JL. 1868-1869. New Coleoptera collected on the survey for the extension of the Union Pacific Railway, E. D. from Kansas to Fort Craig, New Mexico. Trans. Am. Entomol. Soc. 2:49-59

55. Levine E, Gray ME. 1994. Use of cucurbitacin vial traps to predict corn rootworm (Coleoptera: Chrysomelidae) larval injury in a subsequent crop of corn. F. Entomol. Sci. 29:590-600

56. Levine E, Oloumi-Sadeghi H. 1991. Management of diabroticite rootworms in corn. Annu. Rev. Entomol. $36: 229-55$

57. Levine E, Oloumi-Sadeghi H. 1996. Western corn rootworm (Coleoptera: Chrysomelidae) larval injury to corn grown for seed production following soybeans grown for seed production. 7 . Econ. Entomol. 89:1010-16

58. Levine E, Oloumi-Sadeghi H, Ellis CR. 1992. Thermal requirements, hatching patterns, and prolonged diapause in western corn rootworm (Coleoptera: Chrysomelidae) eggs. F. Econ. Entomol. 85:2425-32

59. Levine E, Oloumi-Sadeghi H, Fisher JR. 1992. Discovery of multiyear diapause in Illinois and South Dakota northern corn rootworm (Coleoptera: Chrysomelidae) eggs and incidence of the prolonged diapause trait in Illinois. 7. Econ. Entomol. 85:262-67

60. Levine E, Spencer JL, Isard SA, Onstad DW, Gray ME. 2002. Adaptation of the western corn rootworm to crop rotation: evolution of a new strain in response to a management practice. $\mathrm{Am}$. Entomol. 48:94-107

61. Liebhold AM, Tobin PC. 2008. Population ecology of insect invasions and their management. Annu. Rev. Entomol. 53:387-408

62. Mabry TR, Spencer JL. 2003. Survival and oviposition of a western corn rootworm variant feeding on soybean. Entomol. Exp. Appl. 109:113-21

63. Mabry TR, Spencer JL, Levine E, Isard SA. 2004. Western corn rootworm (Coleoptera: Chrysomelidae) behavior is affected by alternating diets of corn and soybean. 2004. Environ. Entomol. 33:860-71

64. McPherson RM, Douce GK, Riley DG. 1996. Summary of Losses from Insect Damage and Costs of Control in Georgia 1995. Univ. Ga. Spec. Publ. 90.54 pp.

65. Meinke LJ, Siegfried BD, Wright RJ, Chandler LD. 1998. Adult susceptibility of Nebraska western corn rootworm (Coleoptera: Chrysomelidae) populations to selected insecticides. F. Econ. Entomol. 91:594-600

66. Melhus IE, Painter RH, Smith FO. 1954. A search for resistance to the injury caused by species of Diabrotica in the corns of Guatemala. Iowa State Coll. 7. Sci. 29:75-94 
67. Meloche F, Filion P, Tremblay G, LeSage L. 2001. Avancée de Diabrotica virgifera virgifera [Coleoptera: Chrysomelidae] dans les champs de maïs au Québec et collecte dans le soja á Ottawa, Ontario. Phytoprotection 82:35-38

68. Meloche F, Hermans P. 2004. Eastward expansion and discovery of the soybean biotype of western corn rootworm (Diabrotica virgifera virgifera LeConte) in Canada. Can. 7. Plant Sci. 84:305-9

69. Meloche F, Rhainds M, Roy M, Brodeur J. 2005. Distribution of western and northern corn rootworms (Coleoptera: Chrysomelidae) in Quebec, Canada. Can. Entomol. 137:226-29

70. Metcalf RL. 1983. Implications and prognosis of resistance to insecticides. In Pest Resistance to Pesticides, ed. GP Georghiou, T Saito, pp. 703-33. New York: Plenum

71. Metcalf RL. 1986. Foreword. In Methods for the Study of Pest Diabrotica, ed. JL Krysan, TA Miller, pp. vii-xv. New York: Springer. 260 pp.

72. Miller N, Estoup A, Toepfer S, Bourguet D, Lapchin L, et al. 2005. Multiple transatlantic introductions of the western corn rootworm. Science 310:992

73. Miller NJ, Ciosi M, Sappington TW, Ratcliffe ST, Spencer JL, Guillemaud T. 2007. Genome scan of Diabrotica virgifera virgifera for genetic variation associated with crop rotation tolerance. 7 . Appl. Entomol. 131:378-85

74. Miller NJ, Kim KS, Ratcliffe ST, Estoup A, Bourguet D, et al. 2006. Absence of genetic divergence between western corn rootworms (Coleoptera: Chrysomelidae) resistant and susceptible to control by crop rotation. 7. Econ. Entomol. 99:685-90

75. Mitchell PD, Gray ME, Steffey KL. 2004. A composed-error model for estimating pest-damage functions and the impact of the western corn rootworm soybean variant in Illinois. Am. F. Agric. Econ. 86:332-44

76. Moeser J, Hibbard BE. 2005. A synopsis of the nutritional ecology of larvae and adults of Diabrotica virgifera virgifera (LeConte) in the new and old world: nouvelle cuisine for the invasive maize pest Diabrotica virgifera virgifera in Europe? In Western Corn Rootworm: Ecology and Management, ed. S Vidal, U Kuhlmann, CR Edwards, 3:41-66. UK: CABI Publ. 320 pp.

77. Moeser J, Vidal S. 2004. Do alternative host plants enhance the invasion of the maize pest Diabrotica virgifera virgifera (Coleoptera: Chrysomelidae) in Europe? Environ. Entomol. 33:1169-77

78. Moeser J, Vidal S. 2004. Response of larvae of the invasive maize pest Diabrotica virgifera virgifera (Coleoptera: Chrysomelidae) to carbon/nitrogen ration and phytosterol content of European maize varieties. 7. Econ. Entomol. 97:1335-41

79. Moeser J, Vidal S. 2005. Nutritional resources used by the invasive maize pest Diabrotica virgifera virgifera in its new Southeast European distribution range. Entomol. Exp. Appl. 114:55-63

80. Moeser J, Vidal S. 2006. Resistente Maissorten als Management-Option gegen den invasiven Maiswurzelbohrer. Mitt. Biol. Bundeanstalt 400:446-47

81. Mollison D. 1986. Modeling biological invasions: chance, explanation, prediction. Philos. Trans. R. Soc. London Ser. B 314:675-93

82. Nowatzki TM, Lefko SA, Binning RR, Thompson SD, Spencer TA, Siegfried BD. 2008. Validation of a novel resistance monitoring technique for corn rootworm (Coleoptera: Chrysomelidae) and Event DAS-59122-7 maize. 7. Appl. Entomol. 132:177-88

83. O’Neal ME, DiFonzo CD, Landis DA. 2002. Western corn rootworm (Coleoptera: Chrysomelidae) feeding on corn and soybean leaves affected by corn phenology. Environ. Entomol. 31:285-92

84. O’Neal ME, Gray ME, Ratcliffe S, Steffey KL. 2001. Predicting western corn rootworm (Coleoptera: Chrysomelidae) larval injury to rotated corn with Pherocon AM traps in soybeans. F. Econ. Entomol. 94:98-105

85. O’Neal ME, Gray ME, Smyth CA. 1999. Population characteristics of a western corn rootworm (Coleoptera: Chrysomelidae) strain in east-central Illinois corn and soybean fields. 7. Econ. Entomol. 92:1301-10

86. O’Neal ME, Landis DA, Miller JR, DiFonzo CD. 2004. Corn phenology influences Diabrotica virgifera virgifera emigration and visitation to soybean in laboratory assays. Environ. Entomol. 33:35-44

87. Onstad DW, Crowder DW, Isard SA, Levine E, Spencer JL, et al. 2003. Does landscape diversity slow the spread of rotation-resistant western corn rootworm (Coleoptera: Chrysomelidae)? Environ. Entomol. 32:992-1001
72. Demonstrated that there have been several independent introductions of western corn rootworm from North America into Europe. 
89. Predicted the dispersal of the variant western corn rootworm across the Corn Belt of the United States.

94. Large field experiments demonstrated different ovipositional characteristics by the rotation resistant western corn rootworm.

99. Demonstrated that entomopathogenic nematodes exploit chemical cues secreted by damaged maize plants to locate western corn rootworm larvae.
88. Onstad DW, Crowder DW, Mitchell PD, Guse CA, Spencer JL, et al. 2003. Economics versus alleles: balancing integrated pest management and insect resistance management for rotation-resistant western corn rootworm (Coleoptera: Chrysomelidae). 7. Econ. Entomol. 96:1872-85

89. Onstad DW, Joselyn MG, Isard SA, Levine E, Spencer JL, et al. 1999. Modeling the spread of western corn rootworm (Coleoptera: Chrysomelidae) populations adapting to soybean-corn rotation. Environ. Entomol. 28:188-94

90. Onstad DW, SpencerJL, Guse CA, Levine E, Isard SA. 2001. Modeling evolution of behavioral resistance by an insect to crop rotation. Entomol. Exp. Appl. 100:195-201

91. Oyediran IO, Hibbard BE, Clark TL. 2004. Prairie grasses as hosts of the western corn rootworm (Coleoptera: Chrysomelidae). Environ. Entomol. 33:740-47

92. Pascual M, Chapuis MP, Mestres F, Balanyà J, Huey RB, et al. 2007. Introduction history of Drosophila subobscura in the new world: a microsatellite-based survey using ABC methods. Mol. Ecol. 16:3069-83

93. Pierce CMF, Gray ME. 2006. Seasonal oviposition of a western corn rootworm, Diabrotica virgifera virgifera LeConte (Coleoptera: Chrysomelidae), variant in east central Illinois commercial maize and soybean fields. Environ. Entomol. 35:676-83

94. Pierce CMF, Gray ME. 2006. Western corn rootworm, Diabrotica virgifera virgifera LeConte (Coleoptera: Chrysomelidae), oviposition: a variant's response to maize phenology. Environ. Entomol. 35:423-34

95. Pilz C, Wegensteiner R, Keller S. 2007. Selection of entomopathogenic fungi for the control of the western corn rootworm Diabrotica virgifera virgifera. F. Appl. Entomol. 131:426-31

96. Pilz C, Wegensteiner R, Keller S. 2008. Natural occurrence of insect pathogenic fungi and insect parasitic nematodes in Diabrotica virgifera virgifera populations. Biocontrol 53:353-59

97. Purdue University. 2008. Western corn rootworm. http://www.entm.purdue.edu/wcr

98. Rannala B, Mountain JL. 1997. Detecting immigration by using multilocus genotypes. Proc. Natl. Acad. Sci. USA 94:9197-201

99. Rasmann S, Kollner TG, Degenhardt J, Hiltpold I, Toepfer S, et al. 2005. Recruitment of entomopathogenic nematodes by insect-damaged maize roots. Nature 434:732-37

100. Riedell WE, Evenson PD. 1993. Rootworm feeding tolerance in single-cross maize hybrids from different eras. Crop Sci. 33:951-55

101. Rondon SI, Gray ME. 2003. Captures of western corn rootworm (Coleoptera: Chrysomelidae) adults with Pherocon AM and vial traps in four crops in east central Illinois. 7. Econ. Entomol. 96:737-47

102. Rondon SI, Gray ME. 2004. Ovarian development and ovipositional preference of the western corn rootworm (Coleoptera: Chrysomelidae) variant in east central Illinois. F. Econ. Entomol. 97:390-96

103. Ruppel RF. 1975. Dispersal of western corn rootworm, Diabrotica virgifera Le Conte, in Michigan (Coleoptera: Chrysomelidae). F. Kans. Entomol. Soc. 48:291-96

104. Sakai AK, Allendorf FW, Holt JS, Lodge DM, Molofsky J, et al. 2001. The population biology of invasive species. Annu. Rev. Ecol. Syst. 32:305-32

105. Sammons AE, Edwards CR, Bledsoe LW, Boeve PJ, Stuart JJ. 1997. Behavioral and feeding assays reveal a western corn rootworm (Coleoptera: Chrysomelidae) variant that is attracted to soybean. Environ. Entomol. 26:1336-42

106. Sappington TW, Siegfried BD, Guillemaud T. 2006. Coordinated Diabrotica genetics research: accelerating progress on an urgent insect pest problem. Am. Entomol. 52:90-97

107. Schroeder JB, Ratcliffe ST, Gray ME. 2005. Effect of four cropping systems on variant western corn rootworm (Coleoptera: Chrysomelidae) adult and egg densities and subsequent larval injury in rotated maize. 7. Econ. Entomol. 98:1587-93

108. Shaw JT, Paullus JH, Luckmann WH. 1978. Corn rootworm oviposition in soybeans. F. Econ. Entomol. 71:189-91

109. Siegfried BD, Waterfield N, ffrench-Constant RH. 2005. Expressed sequence tags from Diabrotica virgifera virgifera midgut identify a coleopteran cadherin and a diversity of cathepsins. Insect Mol. Biol. $14: 137-43$

110. Smith MV. 1983. Northern (Diabrotica longicornis) and western (Diabrotica virgifera) corn rootworm beetles as competitors of foraging honey bees, Apis mellifera. Can. Beekeeping 10:173-74 
111. Smith RF, Lawrence JF. 1967. Clarification of the status of the type specimens of diabroticites. Univ. Calif. Publ. Entomol. 45:174

112. Spencer JL, Isard SA, Levine E. 1999. Free flight of western corn rootworm (Coleoptera: Chrysomelidae) to corn and soybean plants in a walk-in wind tunnel. 7. Econ. Entomol. 92:146-55

113. Steffey KL, Gray ME, Kuhlman DE. 1992. Extent of corn rootworm (Coleoptera: Chrysomelidae) larval damage in corn after soybeans: search for the expression of the prolonged diapause trait in Illinois. 7. Econ. Entomol. 85:268-75

114. Summers CG. 2006. Potential new insect pests of forage crops in California. Univ. Calif. Plant Prot. Q. 16:1-9

115. Sutter GR. 1999. Western corn rootworm. In Handbook of Corn Insects, ed. KL Steffey, ME Rice, J All, DA Andow, ME Gray, JW Van Duyn, pp. 64-65. Lanham, MD: Entomol. Soc. Am. 174 pp.

116. Tate HD, Bare OS. 1946. Corn rootworms. Neb. Agric. Expt. Stn. Bull. 381:3-12

117. Toepfer S, Gueldenzoph C, Ehlers R-U, Kuhlmann U. 2005. Screening of entomopathogenic nematodes for virulence against the invasive western corn rootworm, Diabrotica virgifera virgifera (Coleoptera: Chrysomelidae) in Europe. Bull. Entomol. Res. 95:473-82

118. Tonhasca AJr, Stinner BR. 1991. Effects of strip intercropping and no-tillage on some pests and beneficial invertebrates of corn in Ohio. Environ. Entomol. 20:1251-58

119. Tsutsui ND, Suarez AV, Holway DA, Case TJ. 2000. Reduced genetic variation and the success of an invasive species. Proc. Natl. Acad. Sci. USA 97:5948-53

120. USDA. 2007. National Agricultural Statistics Service. http://www.nass.usda.gov/

121. Wilson TA, Hibbard BE. 2004. Host suitability of nonmaize agroecosystem grasses for the western corn rootworm (Coleoptera: Chrysomelidae). Environ. Entomol. 33:1102-8

122. Wright RJ, Witkowski JF, Echtenkamp G, Georgis R. 1993. Efficacy and persistence of Steinernema carpocapsae (Rhabditida: Steinernematidae) applied through a center-pivot irrigation system against larval corn rootworms (Coleoptera: Chrysomelidae). F. Econ. Entomol. 86:1348-54

123. Youngman RR, Day ER. 1993. Incidence of western corn rootworm beetles (Coleoptera: Chrysomelidae) on corn in Virginia from 1987 to 1992. F. Entomol. Sci. 28:136-41 